第 2 表 加 圧 沸 滕の脱珪

\begin{tabular}{|c|c|c|c|c|c|c|c|c|c|c|}
\hline \multirow{2}{*}{ No. } & \multirow{2}{*}{$\frac{\text { 添 }}{\mathrm{MgO} \text { と } \tau}$} & \multicolumn{2}{|c|}{ 加 } & \multicolumn{2}{|c|}{ 处理条件 } & \multicolumn{3}{|c|}{ 处理後の溶液 } & \multirow{2}{*}{$\begin{array}{c}\mathrm{SiO}_{2} \\
\text { 除去率 } \\
(\%)\end{array}$} & \multirow{2}{*}{$\frac{\text { 除去 } \mathrm{SiO}_{2}}{\text { 不溶 } \mathrm{MgO}}$} \\
\hline & & $(\mathrm{mg} / \mathrm{l})$ & $\mathrm{SiO}_{2}$ & ${ }_{\left({ }^{\circ} \mathrm{C}\right)}^{\text {度 }}$ & $\begin{array}{c}\text { 時 間 } \\
(\mathrm{hr})\end{array}$ & $\mathrm{pH}$ & $\mathrm{MgO} \tau_{(\mathrm{mg} / l)}$ & $\mathrm{SiO}_{2}$ & & \\
\hline 1 & 38.5 & & 95 & 197 & 3 & 9.4 & 0.0 & 55 & 42 & 1.04 \\
\hline 2 & 38.4 & & 11 & 196 & 11 & 10.2 & 0.5 & 54 & 43 & 1.08 \\
\hline 3 & 39.5 & & "I & $\prime \prime$ & 2.5 & 10.8 & 0.0 & 57 & 40 & 0.96 \\
\hline 4 & 83. 6 & & $" \prime$ & 197 & 3 & 10.2 & $\prime \prime$ & 23 & 76 & 0.86 \\
\hline 5 & 75.9 & & 11 & 11 & 4 & 10.4 & "I & 25 & 74 & 0.93 \\
\hline 6 & 76.3 & & "I & 196 & 2.5 & 11.0 & $\prime \prime$ & 20 & 79 & 0.98 \\
\hline 7 & 75.8 & & 11 & "I & 11 & 11.5 & 0.2 & 27 & 72 & 0.90 \\
\hline 8 & 118 & & 94 & 194 & $\prime \prime$ & 10.5 & 0.0 & 4 & 96 & 0.76 \\
\hline 9 & 120 & & 95 & $\prime \prime$ & "I & 10.7 & $\prime \prime$ & 2 & 98 & 0.77 \\
\hline 10 & 11 & & $\prime \prime$ & " & "I & 11. 2 & $\prime \prime$ & 3 & 97 & "I \\
\hline 11 & 59.9 & & 47 & 11 & 11 & 10.4 & 11 & 1 & "I & $" \prime$ \\
\hline 12 & $\prime \prime$ & & $" \prime$ & $\prime \prime$ & "I & 10.7 & "I & "I & $\prime \prime$ & "l \\
\hline 13 & 60.0 & & "I & $\prime \prime$ & "I & 10.9 & "I & 2 & 95 & $0.7 \dot{5}$ \\
\hline $.14 *$ & $(16.5)$ & & (49) & 11 & $\prime \prime$ & 10.8 & "I & 16 & 66 & 1.96 \\
\hline $15 *$ & $(46.5)$ & & $(\prime \prime)$ & "I & "I & 10.7 & "l & 2 & 97 & 1.00 \\
\hline $16^{*}$ & $(66.5)$ & & $(11)$ & "I & "I & 10.8 & - 3.2 & 1 & 99 & 0.72 \\
\hline $17 *$ & $(1 /)$ & & $(11)$ & Ir & "I & 10.3 & 0.3 & 11 & "I & 11 \\
\hline
\end{tabular}

註 *は原水中の做に添加した值を加えたもの

$\mathrm{MgO}: 16.5, \mathrm{SiO}_{2}: 49 \mathrm{mg} / l$ ), 原水中の $\mathrm{MgO}$ と添加した $\mathrm{MgO}$ する。

との和について考えれば良い。

\title{
4. 加区沸腾の実験
}

内容䄪 $1 l$ の不銹鋼製オートクレーブを用い, 約 $195^{\circ} \mathrm{C}, 2.5$ 時間加熱して脱珪。化学用アスベスト不銹鋼の削屏とを詰めた濾 過器と冷却器とを通して加熱中試料を採取し, $\mathrm{pH}$ の測定と $\mathrm{SiO}_{2}$,

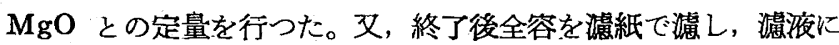
つて $\mathrm{pH}$ の測定, $\mathrm{SiO}_{2}$ と $\mathrm{MgO}$ との定量を行い, 沈澱は $\mathrm{HCl}$ にとかして, $\mathrm{SiO}_{3}$ と $\mathrm{MgO}$.とを定量した。なお, 実験は塩基性 炭酸マグネシウムのみにつき行つた。

実験結果は第 2 表に示す様に常温の場合と異なり， $\mathrm{pH}$ の影響 は著しくなく $\mathrm{pH} 10$ 乃至 11 で大差のない脱珪率を示す。 $\mathrm{MgO} /$ $\mathrm{SiO}_{3}$ の比は脱珪率を左右し，この比が 1.2 位になると脱珪は 完全に近い。No.14 万至 17 は前記茾戸水についての実験結果で 矢張り原水中の $\mathrm{MgO}$ と添加した $\mathrm{MgO}$ との和が脱珪率を支配

\section{5. 結}

約 $30,100,195^{\circ} \mathrm{C}$ で塩基性炭酸マグネシウムを主とした脱珪 の実験を行い，それらの有效な条件をしらべた。その結果

（1） $30^{\circ} \mathrm{C}$ では $\mathrm{pH}$ によつて脱珪率が著しく左右され，夫々 に適当な $\mathrm{pH}$ の範囲がある。塩基性炭酸マグネシウムでは，他の ものより高い 10.2 乃至 10.4 の $\mathrm{pH}$ で最高の脱珪率を示した。

（2） $100^{\circ} \mathrm{C}$ では $\mathrm{pH}$ の影響は（1）より小さく， $\mathrm{MgO} / \mathrm{SiO}_{2}$ が 1.2 乃至 2 で 10 乃至 11 の $\mathrm{pH}$ に於て殆ど完全な脱珪が行 われる。 $\mathrm{Al}(\mathrm{OH})_{3}, \mathrm{Zn}(\mathrm{OH})_{2}$ では $\mathrm{pH}$ が 9 以上になると脱珪率 が低下する。

（3） $195^{\circ} \mathrm{C}$ では $\mathrm{pH}$ の影留は小さく, $\mathrm{MgO} / \mathrm{SiO}_{2}$ を 1.2 位 に保つことによつて $\mathrm{pH} 10$ 乃至 11 で良好な脱珪率を示した。 又, 原水中の $\mathrm{MgO}$ は添加する $\mathrm{MgO}$ と同等に考えてよい。

(昭和 27 年 10 月 18 日，日化関東支部常会講演）

（東京工業大学：東京都目黒区）（昭和 28 年 4 月 22 日受理）

\section{（347）熔成憐肥の高溫に於ける物理的性質に関する研究（第 4 報）* 熔成苦土燐肥の流動性について}

\author{
清 浦 雷 作・佐 多 敏 之
}

熔融急冷法による熔成苦土橉肥製造の操業温度を如何に取るべ きかについて考察する。先ず Tap hole より出湯して幾何かの 湯渞を流れ，次いで水急冷した場合にガラス状に固化しなければ *) 第 3 報は工化 56,668 (1953).
ならない程度の流動性を持つ温度を最低限とする。又融液が高温 になる程枸溶率は上算するが，その上限は燃料費の增大と共に 耐火物の消耗の問題からおのずと決定される。この操業温度範囲 を決定する本質のものは燐肥融液の流動性に外ならず, 熔成苦士 
燐肥のように脱弗せずに枸溶率を持たしめる操作を要するるので は，流動性は重要な要素となつて来，その上燐肥の組成は鉱石の 種類，品位並に愹融洔間と共に変化して来るから複雑となる。

流動性は粘性係数の逆数として測られ，従つて粘性係数の湘定 が必要となるが，高温に於ける粘性の測定は坩堝の問題で最も困 難であり (黒鉊坩堝では還元雾囲気となる), 又高温の故に多くの 測定誤差か入つて来る1)。我々は白金坩堝を用いたが，その侵蝕 減量も大きいので二，三の測定を行い得たに過ぎないか，粘性の 大要を把握し得たのでここに報告する。

従来ガラス主として $\mathrm{CaO}-\mathrm{SiO}_{2}-\mathrm{Na}_{2} \mathrm{O}$ 系については多くの測 定がなされ，又鉱㳯亚にこれに関連して $\mathrm{CaO}-\mathrm{MgO}-\mathrm{SiO}_{2}-\mathrm{Al}_{2} \mathrm{O}_{3}$ 系について測定されたが， $\mathrm{P}_{2} \mathrm{O}_{5}$ 含有物については測定結果が無 い上うである。

\section{1. 測 定 装 置}

高温に於计る流動性測定法としては，金属合金に対し流動長测 定が広く行われているが，ここでは用いなかつた。粘性の測定は $P t$ 球の沈降速度によつた（約 5 poise 以下は測定不能)。

即ち第 1 困に示寸よ5に 6 本の棒状ェレマよりなる電気炉内の 内径 $40 \mathrm{~mm}$ の内筒内の中央部より, $15 \mathrm{~mm}$ 下の部分に坩堝中 心部が来るよ5に白金坩堝を位置せしめる。試料温度の湘定は予 め試料温度と光高温計とよる表面温度との関係を出して特き, 測 定時法熔融物の表面温度から求めた。これは坩堝外側温度は相当 高く，又坩堝内に熱電対を入れると坩堝壁に附着するからであ る。温度の調節のため内筒の外側の温度を Pt-Pt.Rh 熱電対で 测定しながら $\pm 2^{\circ} \mathrm{C}$ 近傍に調節し得たので, 坩堝内温度は充分 一定温度を保ち得たと思われる。

第 1 図 高温における粘度測定用炬

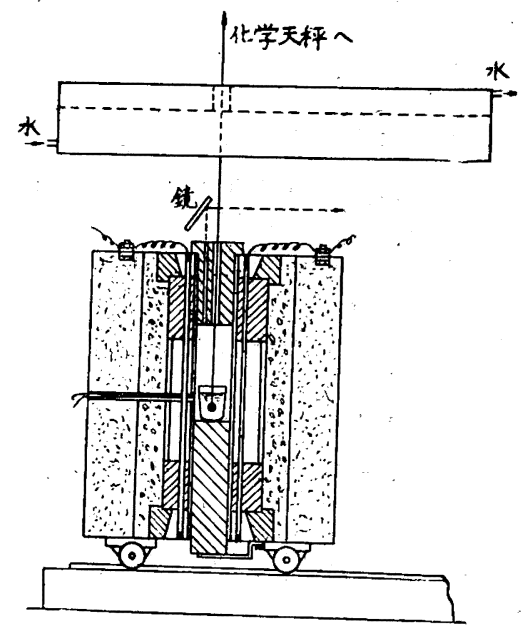

坩堝内に試料粉末をつめて $1400^{\circ} \mathrm{C}$ 前後汇愹融し，後予熱した 塊状試料を補給し，全体を $45 \mathrm{~g}$ とし，適当時閒熔融後，㩱汼し て直ちに白金球を入れ，精密化学天科に釣し，温度を下げつつ約 $25^{\circ} \mathrm{C}$ 每に一定に保ち測定を行い，固化するまで行つた。これら の操作を行らため電気炉には台車を附し移動出来るようにした。 白金球は Pt-Ir 合金で径 $4 \mathrm{~mm}, 0.3 \mathrm{~mm}$ のPt 線を附してい る。坩堝は径 $30 \mathrm{~mm}$, 高さ $35 \mathrm{~mm}$ の白金製で，測定後は温度 を上犁して球を引上げて後，水中に熔融物を出し，残る試料は㙁 酸で溶かして取つた。

1) G. Heidkamp u. K. Endell, Glas. Techn. Ber. 14, 89 (1936).

\section{2. 測 定 法}

球の沈降法によつた。球と線との連結部分が不備のため計算す ることをせず，水飴一水系，及文び潤滑油を用いて較正した。これ らの粘度はガラス管内で鉄球を落下せしめて測定し, Stokes 法

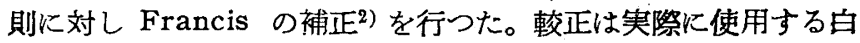
金坩堝内で行い，高温の場合と同様にして行つた。即ち白金球を 適当の荷重を減じて沈降せしめ，その池降速度を天科の指針で測 定し, これを各荷重で行い, 荷重一速度直線の傾斜 $\Delta p / \Delta v$ を求め, これと鉄球の落下法による粘度との関係を得た ${ }^{3)}$ 。この較正曲線 を用いて高温粼肥融液の粘度を測定した。

\section{3. 市販電炉法熔成苦土燐肥の粘度}

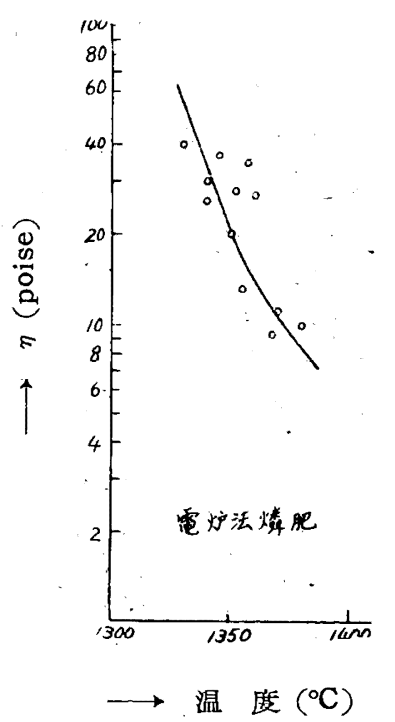

第 2 図電炬法燐肥の粘度

電気师で熔融後急冷したるの で，分析值は $\mathrm{SiO}_{2} 22.97$ ， $\mathrm{Fe}_{2} \mathrm{O}_{3} 2.60, \mathrm{Al}_{2} \mathrm{O}_{3} 2.32$, $\mathrm{CaO} 32.05, \mathrm{MgO} 20.93$, $\mathrm{P}_{2} \mathrm{O}_{5} 19.66 \%$ である。圦堝 内の試料を $1400 \sim 1450^{\circ} \mathrm{C}$ と して約 1 時間熔融せしめて後 温度を下降或いは上升せしめ つつ行い，第 2 図の如き結果 を得た。 $1330^{\circ} \mathrm{C}$ になると急 激に固化し湘定不能となっ た。この温度は前報の方法に よる熔融落下温度と一致す る。

\section{4. フロリダ燐鉱配 合物の粘度}

配合㹥次表の如くで，前報に示した様に最低融点を示す組成で ある。結果を第 3 及び第 4 図に示す。

\begin{tabular}{lcccc} 
No. & フロリダ憐叙 & デュナイト & 珪石 & T- $\mathbf{P}_{\mathbf{2}} \mathrm{O}_{\mathbf{5}}$ \\
\hline FL-3 & 38 & -48 & 14 & $13 \%$ \\
FL-13 & 52 & 36 & 12 & $18 \%$
\end{tabular}

FL-3 の測定值のバラッキは相当あるが, 前項の場合と同様で ある。水急冷物は微細結晶集合体で, 前項の様にガラス状ではな かつた。 $1330^{\circ} \mathrm{C} て ゙$ 固化, 測定不能となつた。この温度は熔融落 下温度 $1270^{\circ} \mathrm{C}$ に較べて高く，この点でも熔融不充分であること 第3因·FL-No.3 の粘度 を示しており，前項の場合より粘

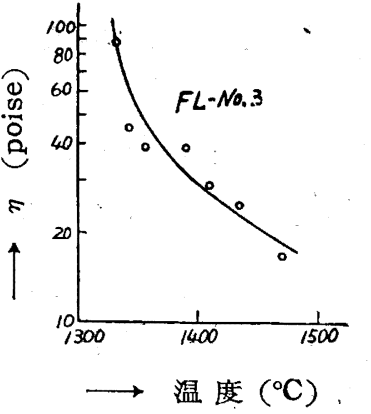
性は大きい。。

$\mathrm{FL}-13$ は $1400 \sim 1450^{\circ} \mathrm{C}$ に 1 時 間熔融後測定したが，次第に粘性 が降下する現象が見られたので， 約 12 時間熔融後測定した結果を 実線で示し，初期の湘定を点線で 示す。 12 時間撘融後のものは透 明に熔骶し，冷しても結晶化せず ブラスの様によく引くことが出来

2) W. Francis, Physics 4, 403 (1933).

3) V. H. Stott, E. Irvine, D. Turner, Hroceed. Royal Soc. London 108 A, 154 (1925). 
第 4 図 FL-No.13 の粘度

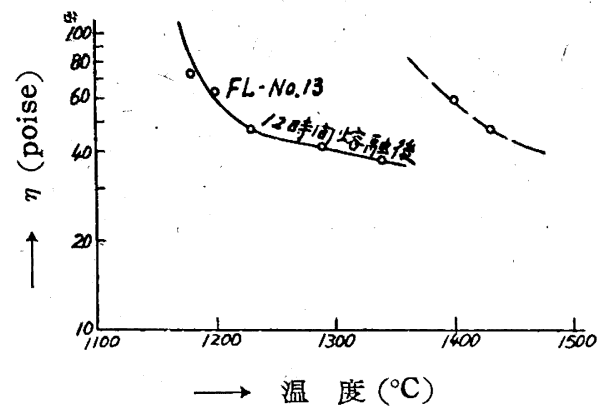

径 $1 \mathrm{~mm}$ の膨張試料を取ることが出来た。かく充分熔融したも のの粘性は下り, 又結晶析出が低温まで起らず， $1180^{\circ} \mathrm{C} て ゙$ 固化し て測定不能となつた。

\section{5. 比重及び膨張係数の測定}

比重：白金球が小さいので精確な測定が出来なかつた。一例 を示すと電炉法熔成苦土燐肥（第 3 項所載）の場合, 常温でピク ノメータ法によれば 3.01 であり， $1380^{\circ} \mathrm{C}$ では 2.58 であつだ。

膨張係数：FL-13 愹融物より引いた径 $1 \mathrm{~mm}$ の試料につい て測定した結果を第 5 困に示す。 $600^{\circ} \mathrm{C}$ 附近まで直線的て膨張す。 るが，後次第に收縮を始め， $730^{\circ} \mathrm{C}$ で急激に収縮する。この場合 ガラスの場合に見られる急膨張の行われる転移点は認められなが つた。 $600^{\circ} \mathrm{C}$ までの膨張俰数は $9.90 \times 10^{-6}$ である。

第 5 困 FL-No. 13 熔諞後冷却物の膨張測定

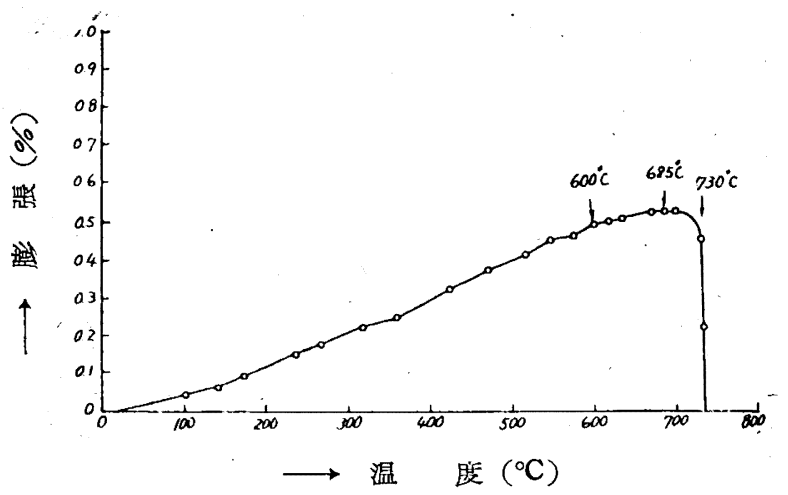

6. 考察

粘度測定から判る様に，粉末混合物から均一な融液を作ること が困難なことが判る。俺かの固体の微粒が存在してもその粘性は 非常に大きくなり4)，結晶の析出も容易となる。熔融侍間と共に 次第に粘性が下つて来ることが認められた。これは融液の均一化 に由来するものと考えられる。電炉法による市販の熔成苦土燐 肥は $1300^{\circ} \mathrm{C}$ で約 100 poise, $1400^{\circ} \mathrm{C}$ で 5 poise を示した。 Endell ${ }^{5 y}$ 等によれば, 高炉鉱㳯の出湯時の粘度の最上限は 75 poise と述べており，又 Keilb) とよれば出㳯特は 1〜5 poise であると述べている。このことから考光て熔成燐肥の出湯温度は 少くとも $1300^{\circ} \mathrm{C}$ 以上であり，1400 $1500^{\circ} \mathrm{C}$ を必要とすると考 えられる。充分熔融時間をかければ更に低温でも高い构溶率が得 られるであろ5。FL-3 欢び FL-13 の測定から判る様に, 熔踊 の初期には大きな粘度指数を示すようであるが，熔融時間が長く なると共に粘度指数は減少し，同時に低温に於计る結晶の生成が

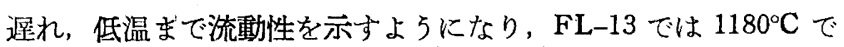
遂に固化する。このことから考えて间報で求めた軟化点は, 操業 時原料粉末混合物の軟化点であつて, 熔融物のそれよりは相当高 い温度を示している様である。

耐火物の侵蝕は侵蝕物質の化学組成よりる，その粘性に著しく 影響され7)，Endell は愹融点より $50^{\circ} \mathrm{C}$ 以上で耐火物を使用する ことは望ましくないと述べている。従つて出来るだけ高温操業を 欲する熔成憐肥の場合, 熔融温度が $1450 \sim 1500^{\circ} \mathrm{C}$ 前後では著し い侵蝕度を示すこ.とが充分考えられる。

燐肥融液の比重は白金球が小さいため小数以下 2 析を求め得た に過ぎないが，比重は师底煉瓦の浮上とも一応関係があり，又炬 の設計上重要な数值となることは言を俟たない。

（昭和 28 年 4 月 3 日，日化第 5 年会講演）

終りに臨み装置の組立は上西義介，鉿木博良雨氏にようて行わ れたことを附記し感謝の譩を表する。

4) E. Lips, H. Nipper, Giesserei 25, 369 (1938).

5) K. Endell u. R. Kley, Stahl u. Eisen 59, 677 (1939).

6) Keil, "Hochofen Schlacke", Stahleisen M. B. H. Dusseldolf, S. 23 (1950).

7) K. Endell, Ber. deut. keram. Ges. 19, 491 (1938).

（大阪大学工学部応用化学教室：大阪市都島区）（昭和 28 年 5 月 1 日受理）

\section{（348） ジルコニウム轁製に関する研究 (第 2 報 $)^{11}$ ・ジルコニウム鞻製について}

\section{石野俊夫・塩川二朗・島野僚祐}

\section{1. 緒言}

ジルコニウム塩類を使用して裸皮を晸寸方法は I. G. Farbenind, A-G2), G. Mauthe, H. Noerr ${ }^{3)}$ 等の特許があり, 更に

1) 第 1 報は工化 56,670 (1953).

2) I. G. Farbenind, A-G, F.P. 798, 137 (1936).

3) G. Mauthe, H. Noerr, U.S.P. 2, 129, 854(1938).
近年 I. C. Sommervilled) やH. G. Turley5) 等はジルュニウ 么の種々の塩類を使用して鞖製を行い, 耐黳, 耐水性の優れた革を 得たと報告している。著者等は前報にて各種のジルコニウム鞖凪

4) I. C. Sommerville, J. Am. Leather Chem. Assoc. 37,381 (1942).

5) I. C. Sommerville, H. G. Turley, ibid. 38, 326 (1943). 